\title{
Henry Dyer Remembers: A Social History of Old Lautoka and Namoli Village, Fiji, 1962-2000
}

\author{
Henry Dyer Tuidraki and Kieran James* \\ Kieran James, School of Business and Enterprise, University of the West of Scotland, Scotland \\ *Corresponding author: Kieran James, School of Business and Enterprise, University of the West of Scotland, Scotland
}

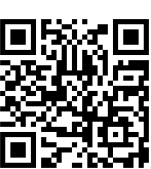

\begin{tabular}{|c|c|}
\hline ARTICLE INFO & ABSTRACT \\
\hline Received: 幽 June 21, 2019 & Keywords: Fiji History; Fiji Islands; Fiji Social History; Lautoka City; Old Lautoka; Pacific \\
\hline Published: 㓞 June 25, 2019 & 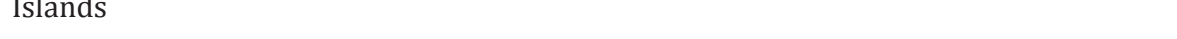 \\
\hline
\end{tabular}

Citation: Henry Dyer Tuidraki, Kieran James. Henry Dyer Remembers: A Social and Religious History of Old Lautoka and Namoli Village, Fiji, 1962-2000. Biomed J Sci \& Tech Res 19(1)-2019. BJSTR. MS.ID.003259.

\section{Section One-A Social and Religious History of Old Lautoka, 1962-2015, by Henry Dyer Tuidraki and Kieran James}

This section discusses the restaurants and nightlife of old Lautoka City, Fiji Islands, in the 1960s through to the 1990s, as recalled by the ex-Nadi and Fiji soccer champion Henry Dyer Tuidraki in interview with Kieran James on April 16, 2015. Lautoka has changed. Today there are new buildings as compared to the colonial buildings of the first business houses. There were only a few Chinese people before at that time. I (Henry Dyer) remember Eddie Hin and Kum Poi. I was brought up with some of them then in the early-1960s through to the 1970s. We went to church with most of the Chinese community at the Evangelical Fellowship Church which was located just beside Jasper Williams High School. The church still stands today. The pastor then was Pastor Cairns. His son, Pastor Cairns Junior, took over. This is when I learned about the Chinese community at an early age as I became friends with them. One of the Chinese children (Graeme Leung) became the chairperson or president of the Law Society (Figure 1) depicts Fiji Islands with Lautoka City and Nadi Town being seen in the upper- left (north-west) quartile of the largest island Viti Levu. (Figure 2) provides a map of Lautoka City Center, featuring Churchill Park, Namoli Village, Naviti Street, and Hunter's Inn Nightclub which is housed within the Lautoka Hotel compound on Tui Street (and is marked by the initials LH on the map).

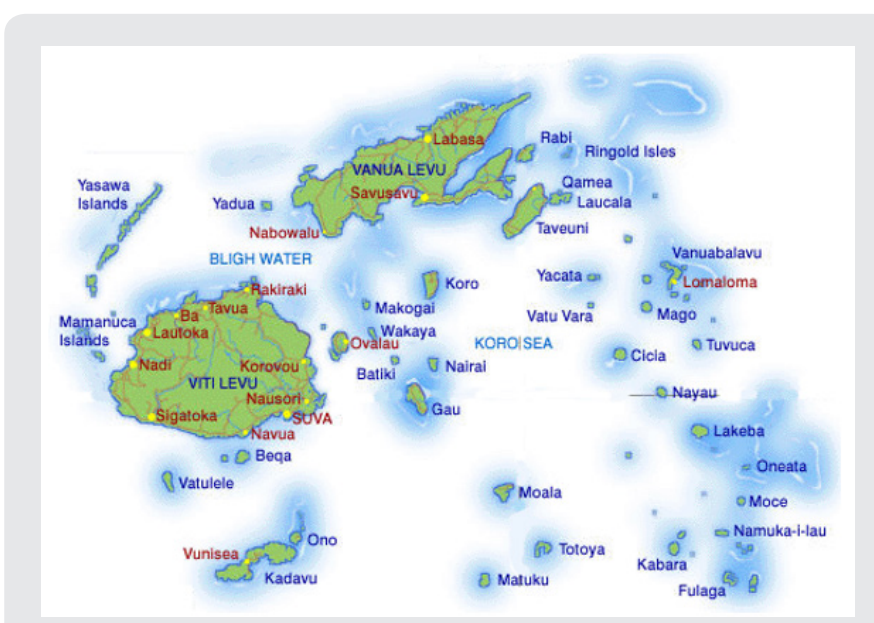

Figure 1: Map of Fiji. 


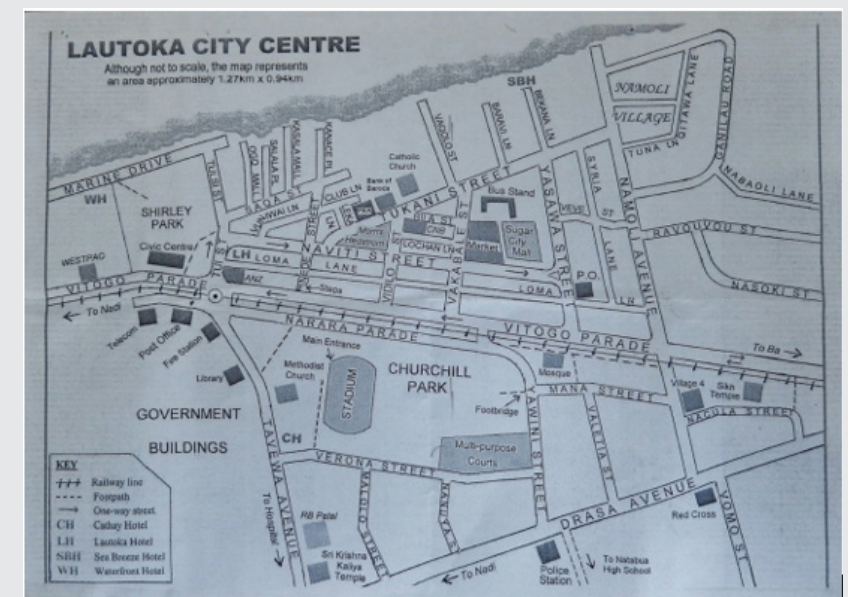

Figure 2: LAUTOKA CITY CENTER MAP (Showing Churchill Park and Namoli Village).

Most of the Chinese restaurateurs have moved on to different businesses. One of the restaurants then was Yang's, located beside the Globe Theater. The Globe Theater was located on the corner of Naviti Street and Vakabale Street just opposite Jolly Good Restaurant and the market. A Chinese provision and lolly shop is located there today (i.e. April 16, 2015). Yang's Restaurant was located around three stores away from Globe Theater, further down on Naviti Street (in the direction towards MH and Nan Yang Seafood Restaurant). Business in Lautoka then was very slow compared to today. Inside the Filipino tailor shop today (opposite the market on Vakabale Street) you can still see the stairway which used to lead up to the Globe Theater. The restaurant called The Great Wall of China Restaurant on Naviti Street (opposite Renee's Pub) was not open then. Those Chinese came in later although now I have heard that that family claims to be the leader of the Chinese community in Lautoka.

There was also the Crown Theater. It had wooden walls. It is where Infashion store is located today on Vitogo Parade. It was really old when we started going to cinemas then. I don't know for how long it had been standing before I was born in the early-1960s. The third cinema was the Mayfair Theater which was located where Village 4 is today. Crown Theater closed down a long way back, years before the Globe Theater closed. This was probably due to its age. It might have been difficult to resurrect it. There were only two curry house shops in Lautoka, Narsey's and Bombay Lodge. Narsey's was located beside the Pacific Transport Headquarters which is now one of those big takeaway restaurants in Lautoka. Narsey's was located on Yasawa Street; it was about the sixth shop from the corner and opposite from the bus station. At Narsey's they had a variety of curries and they were the best in town then. I remember because, when I first worked as a dockworker at Lautoka Wharf (age 17) when I got my pay (around \$17-per-shift which was big money), I used to see the drift of the dockworkers towards this curry house. This is how and when I got my first taste of curry restaurant food in Lautoka. Today this restaurant is still there but with a different owner and a different name. Back then to have a meal away from home was like going to America and coming back. It seemed like that to me then as a child.

There were other curry houses such as Bombay Lodge on Naviti Street (opposite Sugar City Mall) but Narsey's was a famous place and everyone was heading there. Bobby Tikaram, ex-Airport Soccer Club president, says of the Yasawa Street curry house: "First it was Bombay Lodge then new owners took over and named it Narsey's Lodge" (source: Facebook comment, April 26, 2019). Yang's Restaurant was the top-class restaurant in Lautoka then. They would fix the dish up with real Chinese spices. It was a top-class restaurant and not just a café or takeaway shop. There was another Chinese restaurant, Eddy Hin's. They still have this restaurant but I don't know who the owners are now. Nan Yang Seafood Restaurant is located in the same shop too. There were only two Chinese restaurants back then. More people went to Yang's probably due to its location near to the bus station, the center of town, and the taxis. At that time the Indian community was very closely-knit. They did not mingle with the (indigenous) Fijians much perhaps due to fear of discrimination. It was very hard to play soccer on the field with the Indian children. They had a soccer ball and you would sit on the side-lines waiting to play and they would say "no Fijians" perhaps because we were perceived to be stronger and rougher. At night you would seldom see an Indian on the street compared to nightlife today. They have opened up to this side of life much more now. The dress style of the young Indian girls today is different. Back then you would not see girls wearing tight jeans or long pants. They used to just wear Indian clothes such as saris. If you saw an Indian girl then in long pants everyone would look at her and you would hear the passing of remarks. At that time I am sure that the Indian population of Lautoka was significantly higher than it is today because of emigration. There were only four nightclubs in Lautoka. The oldest of them all was Raymond's Night Club. Today it is a warehouse building connected to the wharf. It was right at the edge of the gate to the wharf. This nightclub had a balcony where you could look out towards the Bekana Island, Namoli Village, and beyond. This nightclub was the meeting-place for the local (indigenous) Fijian crowd. The owner was Raymond Wong. His son is Patrick Wong. He is one of the tourism big boys today. As at February 2007 he was the general manager of Matamanoa Island Resort and in 2009 he was Tourism Fiji chairperson. Patrick was a former boxing champion in bantamweight. We used to go to this nightclub just to see what life was like after nightfall.

It used to close around 1:00 a.m. It shut down around the same time as Globe Theater or just prior to that. This would have been in the late-1970s or early-1980s. It was very similar to the atmosphere you find today at Deep Sea Nightclub in Nadi or Renee's Pub in Lautoka. People who have money take the floor and those who go to watch stand aside and wait for the chance to push their way in and take advantage of the benefits. This was just a joke to us as youth. We would sit back and watch how things worked in the nightclub. 
We just wanted to get a buzz before we went home. I remember I was there one night because I wanted to see what life was like in a nightclub. My uncle (Eneri Ratudradral) was a rugby player for Lautoka then. When he saw me he said: "Hey nephew, come here." I thought he was happy to see me. This was in the nightclub. He asked me who I had come with. I said: "With my friends." Then he pulled out his belt and he said: "I want to see you go down these stairs and then run home to the village." He was referring to Namoli Village where I then lived refer to (Figure 3). This did not deter me as we had quite a large group and we would always move together (either to play sports or to go to functions or to see what nightlife was about).

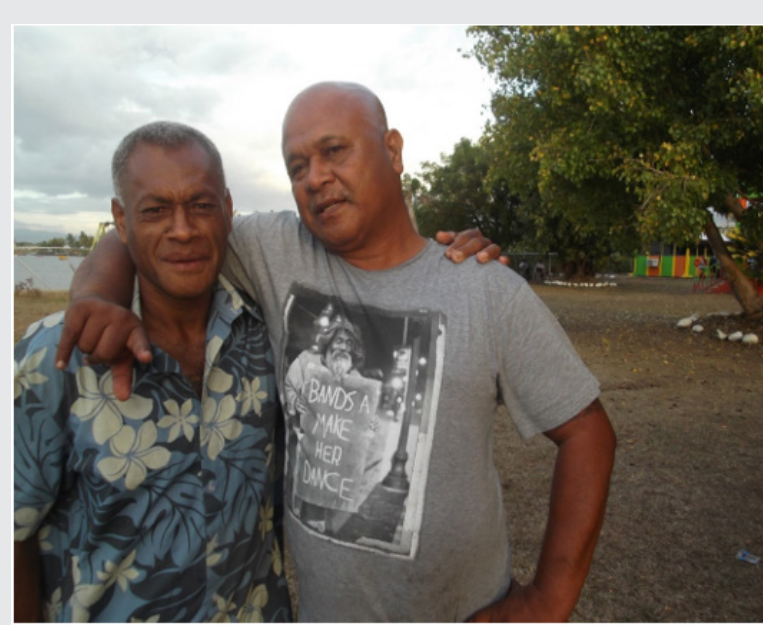

Figure 3: Caption: Henry Dyer (left) \& Lautoka defender Wally Mausio, Lautoka Club, 2014.

The second nightclub was Whiskey Town. This nightclub was located at the top of the stairway next to Bargain Box and near to the Australian betting shop on Vitogo Parade. This nightclub had no escape route. The only way out was the stairwell which you had come up! This nightclub was a very rowdy place perhaps because it was in the town area. It was not open during the daytime. Whiskey Town was more often frequented by the villagers from the Lautoka area than Raymond Wong's nightclub was. The villagers came from Vitogo, Naviago, Vuda, and Namoli. It was easier then for the people from Vuda to come to Lautoka. We used to watch fights breaking out as a result of arguments which spiralled out of control. We would see fights but there was always something more to it than was obvious to people at the time. Sometimes fights would spill out on to Vitogo Parade. This nightclub was closed sometime after Club 21. It was easier for people to go to Whiskey Town because going to Raymond's meant a long walk back home to the village. Raymond's closed down first and then Club 21 and then Whiskey Town. Whiskey Town was at the center of the city and so it was the number one venue for the city's nightlife. This venue was the place where everyone went to for sports and social. It offered easy access to everybody. (Lautoka Club had already opened back then.) Club 21 closed down before Whiskey Town. The location was opposite where Great Wall of China Restaurant is located now on the south side of Naviti Street (about halfway between Vidilo Street and Vakabale Street). I think it is upstairs from next to the Chinese phone shop called Dickson's. There was an indoor spiral staircase up to it which is still there today. This was a nightclub for the young working generation and the school-children. By contrast, Whiskey Town was for the villagers and the local (indigenous) Fijian community. Club 21 had a very good atmosphere because all communities around Lautoka met there. This is where the young generation, which schooled in various places around Lautoka, came to meet up with each other in the evenings. I used to go there when I was in Ba Provincial Secondary School and later. Ba Provincial Secondary School was located at first where the present Housing Authority Office is today (beside Coronation Church).

When I studied at this school it had already moved to its present location. Club 21 was very lax in checking whether you were of drinking age. You just had to look smart and act smart. There were fights there also. Sometimes old rivalries would lead to fights (for example, Waiyavi boys versus Topline boys). (Topline is a suburb on the outskirts of Lautoka.) This was a meeting place too during the eight-week school holidays. It used to be absolutely jam-packed. This nightclub was for all communities but it was mainly patronized by the (indigenous) Fijians and the part-Europeans because the Indians tended to stick to themselves. There were no Indian nightclubs then. The only place that the Indians went to occurred much later. It was opened just a few years back. That is the nightclub opposite the Sugar City Mall on Naviti Street. At that location there used to be the Galaxy Nightclub although it came later than the other nightclubs already mentioned. It only opened in the late1970s. It was for the upper-class. It had a new type of dance-floor, lights underneath the floor, and the flickering balls which lit up the walls. Galaxy Nightclub was also mostly for the Fijians and the partEuropeans. It was later one of the busiest places of them all. In that central location the transport and the food were easily accessible and this factor ensured its popularity. None of the restaurants open now in Lautoka were open back then. Tigers and Jolly Good have only been there for a short period of time (perhaps eight or nine years). I used to go to Lautoka Club but not all that often. I would go there for a drink or for special functions. Figure 3 shows Henry Dyer Tuidraki (left) with the ex-Lautoka Blues defender Wally Mausio at the Lautoka Club in October 2014 (Figure 3).

Sports and Social was another nightclub. At that time there were four nightclubs - Raymond's, Whiskey Town, Club 21, and Sports and Social. Galaxy was opened after Raymond's had closed down. Sports and Social Club was meant for the sports people of Lautoka. It was designed as a place for sportspeople to gather after matches. Sports and Social Club was located right beside Churchill Park. It was a building just to the right of the ticket booth at the Churchill Park main entrance. The building has since been demolished. It was where all the sportspeople and people from all sectors of life would meet together after the game and they would stay there 
until it was time to head home. We enjoyed meeting with the older generation of that time as they enjoyed us serving their beers and we would show respect to them. It gave them a touch of youth again. I remember old George Farrell, Alosi Johns and her husband David Johns (my uncle), Mrs. Millie Ah Tong, and Dr. Tuidraki. They were the regulars of the club during that time. The Sports and Social Club was for the older working crowd. This was their pub. The younger generation sometimes would spill over and mingle with the older guys in the hope of receiving more beers because the older crowd, then as now, had more money. Sports and Social was where the younger generation would look to. It was a Nadi Club type of place but for the matured (indigenous) Fijians. It was patronized by government workers and private-sector workers. There were fights there sometimes when the older respected citizens were not around. The fights used to be extremely brutal because there were two empty streets and a whole playground to use for fights. You had to either fight or run for your life. We used to enjoy it. We would stand on the sugar-cane tramlines and watch. We would see people run or get knocked out. This club was open during the daytime as well. At one stage food was available but then that was stopped. People were very sad when this club closed. This was one of the saddest moments for Lautoka as it was owned by the locals. Even today, when I walk past that place, the memories keep coming back. It has been demolished for over ten years now and nothing has been done. I hope something can be done to resurrect it again.

Club 21 changed its name to Great Wall of China. Now I see a restaurant in Naviti Street called Great Wall of China and I assume that they borrowed the name from the nightclub and/or that there were some connections through maternal links. The real Great Wall person was Raymond Wong (Patrick Wong's father) who also owned Club 21. Patrick Wong is in the tourism sector now. At one time he was managing one of the island resorts. I am really not sure where he is now. Yang's Restaurant was owned by Alfred's family and Eddie Hin's restaurant was owned by, of course, Eddie Hin. He also had a lemonade / soft-drink company. There was a Chinese restaurant in Eddie Hin's building on the ground floor. I don't remember the name of the restaurant. There was a small milk bar there at the entrance to the restaurant.

Many Fijian ladies were working there. This restaurant was open from the mid-1970s to the early-1980s. It may even have existed as far back as the 1960s. I used to go there sometimes when I was a young schoolboy at Drasa Avenue School. (I left Drasa Avenue School in 1975.) I would have a milkshake there for 20 cents. You could sit inside the shop and have a milkshake. There was another milkshake restaurant owned by a Gujarati family called S.B. Maharaj. It was located near the Crown Theater, opposite the hockey grounds. I would meet with other schoolchildren there to have a milkshake. If I had 20 cents spare I would stop there after school to have a milkshake with other Drasa Avenue schoolchildren. Today that milkshake would cost $\$ 3$ or more. The milkshake glass was very tall and very wide (perhaps nine inches by four inches). If I had 40 cents I would have two. It would take until dinner to finish the two milkshakes. I used to enjoy sipping them very slowly. Things back then were very cheap.Other nightclubs opened and closed but they did not have the longevity of the four clubs I have mentioned plus Galaxy Nightclub. At one time there was a lack of nightlife in Lautoka. This was during the mid-1980s. The Sport and Social Club closed around 13 years ago. Before these nightclubs closed people from as far away as Ba, Tavua, and Vatukoula would come down to Lautoka because it was a city. They would enjoy the nightlife and spend the night there. That same crowd from the 1980s then gravitated to Nadi because Lautoka's nightlife had died. By this time I also had moved to Nadi. The crowd would travel from Tavua to as far away as Nadi just to enjoy the nightlife. By that time (late-1980s) the tourism industry in Nadi had just started to boom. Lautoka now has a lot of nightlife again. The community has changed its approach to life. People have become friendlier amongst themselves. The present nightclub at Lautoka Hotel (now called Hunter's Inn) opened sometime during the early-1980s. It is called the Qara Vatu (in English: the Tomb). I remember going there. It was a different style to the other nightclubs. It had a different atmosphere as it appeared that you were really in a stone cave. There were lights, music, and a bar. We used to frequent this place only when we had money. Now the place is for anybody; before it was mostly for the young (indigenous Fijian) crowd from the nearby villages and communities. They all respected each other until it started getting a bit rowdy. My memory is strongest of the places I went to when I was very young which includes neither the Galaxy nor the Tomb.

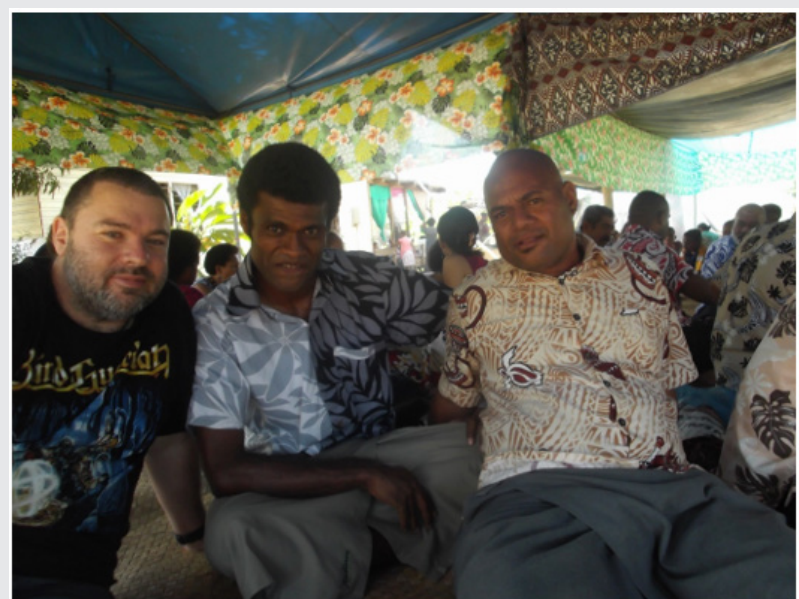

Figure 4: Caption: Kieran James (left) \& Henry's oldest son, Anare "Fella" Tuidraki (centre), Namoli Village, 2014.

There was also a nightclub which opened up in the Namoli Industrial Area (at the back of Namoli Village and close to the sea). This nightclub was also an attraction but unfortunately it did not last for long. This place was frequented mostly by the villagers and the other (indigenous) Fijians. It only lasted for around four or five years. It was great to have a night out there because you had a view of Bekana Island and the lights of the Lautoka Wharf; and you had the breeze. It was owned by a local. I do remember that 
beer was cheap there. I had a lot of friends there as I grew up in Lautoka. I used to really enjoy the nights there. This nightclub was opened much later, around the mid-1990s. Sometimes I would visit because I would frequently go back and forth between Nadi and Lautoka. Since I grew up in Namoli Village I always retain a strong attachment to Lautoka. I have my mother's family residing there too Figure 4 shows the author Kieran James (left) with Henry Dyer's eldest son, Anare "Fella" Tuidraki (centre), at Namoli Village, 2014.

\section{Section Two - The Sea God Visits Namoli Village, by Henry Dyer Tuidraki and Kieran James}

This section discusses the visit of the Sea God to Namoli Village, Lautoka City, Fiji Islands, as recalled by the ex-Nadi and Fiji soccer champion Henry Dyer Tuidraki in interview with Kieran James on April 23, 2015. There is also a discussion about the places which traditional mythology and Christianity inhabit in the minds and hearts of the average Fijian villager today; and how some but not all villagers attempt to integrate these two belief systems, whilst others cling to Christianity and reject earlier traditions. The players who made it to the Fiji team from basketball came from Namoli Village and most of them succeeded because of their early years at the Chinese School's basketball court. (The Chinese School is located opposite Namoli Village on the other side of Namoli Avenue.) They played with the Chinese basketball team from Lautoka. Then they formed a team of their own. Players such as Apolosi Tora made it into the Fiji team. Of the ladies there was Kesaia and Mere Satala. They made the team because the Chinese community was very small and the Chinese could not make up two teams for training. So the village boys would make up the numbers for the second team. The village ladies got involved because of their interest but the Chinese ladies did not participate. Therefore, the Chinese School basketball court made some impact into the lives of the Namoli youth at one stage back then. Their interest was very high. We used to stand on the side-lines near the seaside watching until it was so dark we could not see the ball. It was just a wire-fence at that time. They let us in because we were also contributing to guarding the school. Now there is a brick wall there but then it was just wire. We played until dark or until you could not see the ball. If it was a full moon I (Henry Dyer) remember we played for much longer. I played just for fun but there were much better players than me who understood the game more and had the rhythm for the game. The first basketball team started way before the 1970s. I started using the court as a child in the early-1970s.

The Chinese School is one of the oldest schools in Lautoka. Back then for a (non-Indian) local to school in the Chinese School it was an unusual event. We knew the culture of the Chinese education system there. Behind the Chinese School, where the minibus stand is located today (on Tukani Street), there were bushes and a wild guava plantation.

Fiji has a long history of the sea gods and as kids we knew about this because, being brought up by the sea at Namoli Village, there was this young woman (just a little older than us) who, at twilight of the evening, was possessed by the sea god who appeared on land. He was the sea god of the low tide. We had to take this young woman to her family. They asked the sea god to please leave her alone. They did the Fijian ceremony and asked the sea god: "Why are you giving the young child trouble?" He answered back through the young woman saying: "You are all making too much noise at the place where I surfaced [i.e. the basketball court at the Chinese School]". I experienced this myself. The sea god's name was Rateciyavi (meaning "the twilight low tide.") Twilight was the time when he came up to the surface. Straight after this incident the Chinese School became empty at that time of the evening. The belief was really high and sports training used to be affected. This continued until such a time as some stronger boys came through who said not to believe in it and to carry on training regardless. The girl was set free and the devil disappeared. The sea god used to attract the ladies more. He used to choose the pretty ladies in particular as his victims. I remember that Namoli Village was full of belief because many strange things occurred there. Sometimes when you are a young teenager (aged 14- to 16-years) you want to explore what life is all about. We used to walk around the streets of Lautoka and we were open to all kinds of mischief. However, belief in the ancestral gods was always there in the back of our minds.

The Fijians believe that, before Christianity came, they had their own ancestral gods. Those gods had power and gave them strength. The Christians today (the orthodox ones) treat the Fijian ancestral gods as demons. However, the real native iTaukei person (the hardcore villager) still believes that the ancestral gods exist even though he goes to church. He can mix them with the Christian God in his understanding of the world. However, the (indigenous) Fijians who are really into Christian belief opt to stay away from mixing the two gods. They can mix the two but they opt not to because it is a very dangerous thing. They know that it is a demon (Figure 5) shows Henry Dyer (left) with the ex-Ba and Fiji player Semi Tabaiwalu in Ba Town (Table 1), June 17, 2015

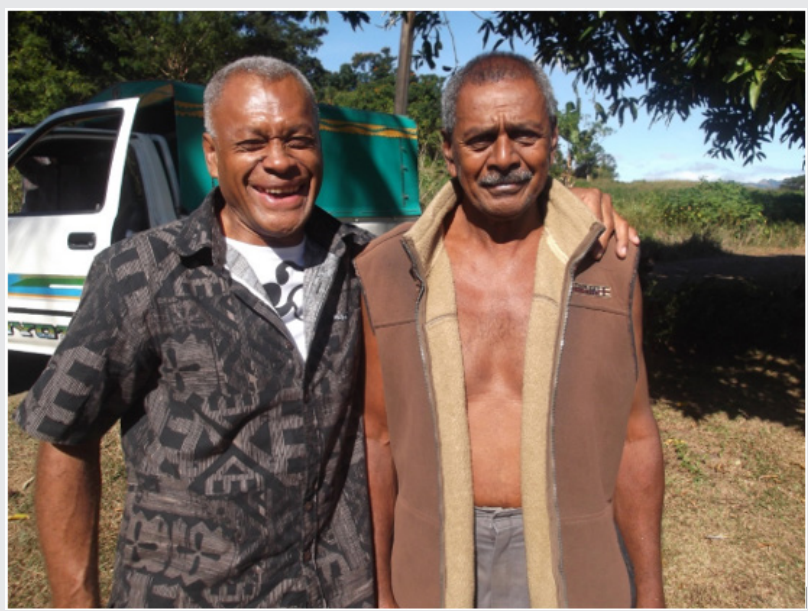

Figure 5: Henry Dyer (left) \& Ba champion Semi Tabaiwalu, June 17, 2015 
Table 1: Fiji versus Newcastle United, Prince Charles Park, Nadi, May 26, 1985.

\begin{tabular}{|c|c|}
\hline Fiji (2) 3 & Newcastle United (0) 0 \\
\hline \multicolumn{2}{|l|}{ Kelemedi Vosuga 10, Rusiate Waqa 15, Sam Work 60.} \\
\hline $\begin{array}{l}\text { Fiji: Savenaca Waqa, Stan Morrell, Abraham Watkins, Henry Dyer, } \\
\text { Keverieli Salesi, Abdul Manaan, Meli Vuilabasa, Sam Work, Rusiate Waqa, } \\
\text { Kelemedi Vosuga, Ivor Evans. }\end{array}$ & $\begin{array}{c}\text { Newcastle United: Martin Thomas, Malcolm Brown, Wesley Saunders, } \\
\text { Gary Megson (Kenny Wharton), Jeff Clarke, Glen Roeder, Neil McDonald, } \\
\text { Tony Cunningham, George Reilly, Peter Beardsley, Paul Gascoigne (Derek } \\
\text { Wright). }\end{array}$ \\
\hline Yellow Carded: Ivor Evans for tripping Reilly from the back. & Neil McDonald for pulling Meli Vuilabasa's jersey from the back. \\
\hline \multicolumn{2}{|l|}{ Venue: Prince Charles Park, Nadi. } \\
\hline \multicolumn{2}{|l|}{ Referee: Gopalan Kanna. } \\
\hline \multicolumn{2}{|l|}{ Crowd: 5,000 . } \\
\hline \multicolumn{2}{|l|}{ Weather: Fine. } \\
\hline \multicolumn{2}{|l|}{ Linesmen: Hari Raj Naicker and Mahendra Singh. } \\
\hline Coach: Billy Singh (Fiji). & Willie McFaul (Newcastle United). \\
\hline
\end{tabular}

While walking in the streets of Lautoka we would be talking about all the collective stories from our individual families. We would be talking about different episodes of the gods. It used to be really scary while walking the streets of Lautoka. There were very few lights on the streets then. When we reached the villages we used to just split up and run to our individual houses. We were afraid that the demons were waiting for us. Sometime we would crash into the front door. Talking about the ancestral gods, I had to spend one of my school holidays with my grandma's household at Tukuvuci. This is close to the Fiji Bitter beer factory. At this same time, as soon as it was dark, my grand-mum (the mother of the Ratudradra brothers) would tell her grandchildren to run up a small hill with a kerosene lantern for 40 meters. She would tell us to run down with the lantern again. She would say: "He's there." We would say: "Who's there?" She would tell us: "Look towards the hills" (Tavakubu Hills and beyond).

Up above the pine trees we would see a light floating over the ridges and the trees in the dark. She would tell us: "There, you see he is playing with us." As a child, I ran up and down that small hill and played with the ancestral gods. I don't know whether the children today will see what I saw then with my own eyes. We children living in that generation at that time were quite fortunate to see a lot of things from the ancient past. We could see it with our eyes. I don't know whether people can see that today or possibly not because Christianity has seeped into every house today. The upbringing in those days was very special. You were taught to obey and to be respectful. You were taught to dress to the occasion. You were taught to always say the right things and not to be rude or offensive. We were taught to respect the older menfolk (the uncles) as they were the next in line to take over in the house. The youngest uncle was respected in the same way that the eldest uncle was. The (indigenous) Fijian protocol was indeed something else.

\section{References}

1. (2015) Interview with Henry Dyer Tuidraki.

2. (2015) Interview with Henry Dyer Tuidraki.

3. (2015) Interview with Semi Tabaiwalu.

4. (2019) Interview with Bobby Tikaram.

5. Chambers C (1985) Fiji team thrash Newcastle United. Fiji Times, p. 24.

6. Masih P (1985) McFaul praises Fiji duo. Fiji Times, p. 3.

\section{ISSN: 2574-1241}

DOI: $10.26717 /$ BJSTR.2019.19.003259

Kieran James. Biomed J Sci \& Tech Res

(C) This work is licensed under Creative Commons Attribution 4.0 License

Submission Link: https://biomedres.us/submit-manuscript.php

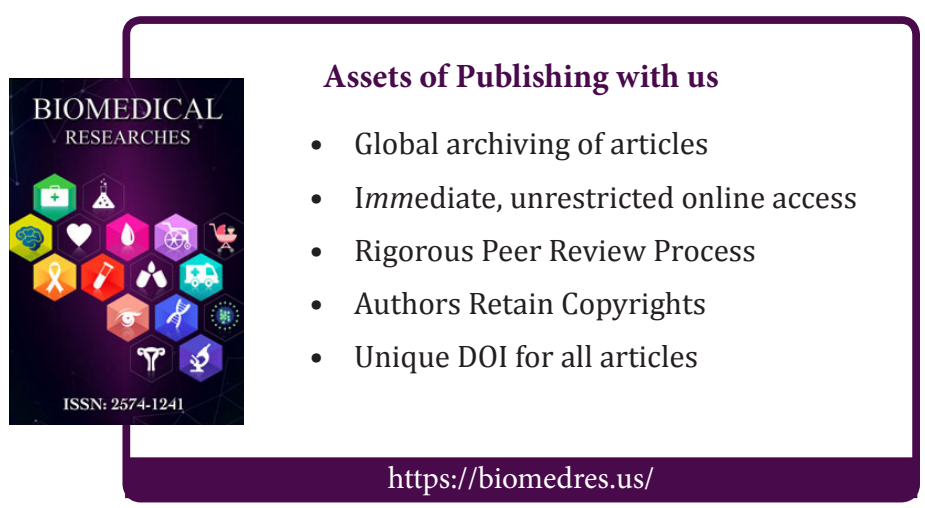

